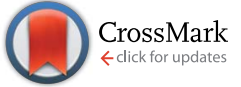

Cite this: RSC Adv., 2017, 7, 13041

\title{
Surface active ionic liquid induced conformational transition in aqueous medium of hemoglobin $\dagger$
}

\begin{abstract}
Rajni Vashishat, Shruti Chabba and Rakesh Kumar Mahajan*
The interaction of human hemoglobin $(\mathrm{Hb})$ with surface active ionic liquids (SAILs), 1-dodecyl-3methylimidazolium chloride $\left[\mathrm{C}_{12} \mathrm{mim}\right][\mathrm{Cl}]$ and 1-hexyl-3-methylimidazolium dodecylsulfate $\left[\mathrm{C}_{6} \mathrm{mim}\right]$ [SDS], has been studied in aqueous medium through various techniques like surface tension, UV-vis spectroscopy, fluorescence spectroscopy, isothermal titration calorimetry (ITC) and dynamic light scattering (DLS). The interactional behavior of SAILs toward $\mathrm{Hb}$ at the air/solution interface is investigated and various interfacial and thermodynamic parameters have also been calculated. The conformational changes in $\mathrm{Hb}$ upon interacting with SAILs have been illustrated from UV-visible measurements in combination with fluorescence spectroscopy. These results indicate that at lower concentration the $\left[\mathrm{C}_{6}\right.$ mim][SDS] monomer forms stronger $\mathrm{Hb}-\left[\mathrm{C}_{6}\right.$ mim] [SDS] monomer complexes as compared to $\left[\mathrm{C}_{12} \mathrm{mim}\right][\mathrm{Cl}]$, whereas at higher concentration $\left[\mathrm{C}_{12} \mathrm{mim}\right][\mathrm{Cl}]$ denatures $\mathrm{Hb}$ more and induces the release of heme from the hydrophobic pocket of $\mathrm{Hb}$. The enthalpy changes were also investigated by using isothermal titration calorimetry (ITC). The dynamic light scattering (DLS) measurements revealed the effect of SAILs on the hydrodynamic diameter $\left(D_{h}\right)$ of $\mathrm{Hb}$.
\end{abstract}

Received 3rd January 2017 Accepted 21st February 2017

DOI: $10.1039 / \mathrm{c} 7 \mathrm{ra00075h}$

rsc.li/rsc-advances
Proteins are frequently utilized in conjugation with various surfactants to control and improve the interfacial tension as well as bulk properties of proteins. In addition surfactants have also been found to induce structural changes in thermodynamically stable conformations of proteins which in turn affect functional activities of proteins. Thus such conformational alterations in proteins due to clashes between surfactants and proteins make the in vitro protein-surfactant studies relevant. There are several reports in literature where surfactants seems to improve interfacial and bulk properties of proteins and also induce conformational alterations of proteins in terms of folding and unfolding, fibril formation of proteins, self aggregation of proteins and affects the biological activity of proteins. ${ }^{15-17}$ Sarrion et al. have studied the binding affinity of dimeric surfactants to calf thymus DNA and demonstrated the effect of spacer length of dimeric surfactants on DNA-surfactants interactions employing spectroscopy, (UV-visible and fluorescence) atomic force microscopy and various other techniques. ${ }^{18}$ The changes in secondary structure of bovine liver catalase in the presence of gemini surfactants and unfolding of protein have also been investigated by Akram et al. ${ }^{19}$ Gebicka and Banasiak have explored the conformational changes in methemoglobin upon binding with anionic surfactants sodium dodecyl sulphate (SDS) and sodium bis(2-ethylhexyl) sulfosuccinate (AOT) and reported the formation of pentacoordinated species in micellar media. ${ }^{20}$ Cationic surfactant hexadecyltrimethylammonium bromide (HTAB) has been reported to induce alterations in terms of unfolding in $\mathrm{Hb}$ using spectroscopy measurements. ${ }^{21}$ The hydrophobic adsorption
Department of Chemistry, UGC-Centre for Advanced Studies, Guru Nanak Dev University, Amritsar-143005, India. E-mail: rakesh_chem@yahoo.com; Fax: +91 183 2258820

$\dagger$ Electronic supplementary information (ESI) available. See DOI: 10.1039/c7ra00075h 
mechanism of two different surfactants, hydrogenated (sodium octanoate (SO)) and fluorinated (sodium perfluorooctanoate (SPFO)) on hemoglobin and number of adsorption sites on $\mathrm{Hb}$ have been studied by Prieto et al. ${ }^{22}$

Over the past few years, the field of surfactant chemistry has anticipated the replacement of conventional surfactants with a new class of surfactants named as surface active ionic liquids (SAILs) due to their tunable physiochemical properties and innate surface activity. ${ }^{23-26}$ A variety of SAILs have been investigated in the literature which are mainly based on imidazolium, pyridinium, morpholinium and pyrrolidinium cations but the imidazolium based SAILs are of specific interest due to their better antimicrobial activity. ${ }^{27-31}$ In these days, the dynamics of binding of SAILs to proteins represents more active area of investigation. There are numerous studies where the effect of SAILs has been investigated on the aggregation behaviour of biopolymers, co-polymers and polyelectrolytes. ${ }^{32-37}$ Singh et al. have investigated the interactions of gelatin protein with room temperature ionic liquids and concluded the effect of hydrophobicity of ionic liquids on the conformation of gelatin. ${ }^{32}$ Miller et al. have studied the thermal stability and conformational changes in myoglobin in the presence of ionic liquids and reported that myoglobin undergoes destabilization and unfolding in the presence of ionic liquids. ${ }^{33}$ Shu et al. have demonstrated the folding-unfolding behaviour of bovine serum albumin in ionic liquids solutions and reported that probing of protein-ionic liquids interactions is method dependent. ${ }^{34}$

Till now, the interactions of SAILs and blood plasma protein hemoglobin have been scarcely investigated. ${ }^{38-40}$ Venkatesu et al. have studied the conformational stability of $\mathrm{Hb}$ in the presence of varying concentrations of ionic liquids using spectroscopy and molecular docking techniques. ${ }^{38}$ In another report they have investigated the interactions and effect of ionic liquids on the stability/destability of $\mathrm{Hb}$ using various techniques. ${ }^{39}$ Thus, the scarcity of such studies in the literature prompted us to carry out a detailed analysis of interaction phenomena in the $\mathrm{Hb}$-SAIL systems because such studies are of prime importance in the field of biotechnological areas. Therefore, with an aim to scrutinize the interactions present between hemoglobin and SAILs herein we have studied the conformational alterations in hemoglobin mediated by SAILs: 1-dodecyl-3-methyl imidazolium chloride $\left[\mathrm{C}_{12} \mathrm{mim}\right][\mathrm{Cl}]$ and 1hexyl-3-methylimidazolium dodecylsulfate $\left[\mathrm{C}_{6} \mathrm{mim}\right][\mathrm{SDS}]$ at $\mathrm{pH}$ 6. In brief we have studied the interactions between hemoglobin and SAILs using a variety of techniques. The tensiometry measurements have been exploited to get better insights into the interaction process and to explore interfacial properties of SAILs in the presence of $\mathrm{Hb}$. The UV-visible spectroscopy, fluorescence spectroscopy and isothermal titration calorimetry were employed to understand the spectroscopic and thermodynamic aspects of $\mathrm{Hb}$-SAILs complex respectively. Dynamic light scattering (DLS) measurements were also carried out to exemplify the variations in hydrodynamic diameter $\left(D_{\mathrm{h}}\right)$ of $\mathrm{Hb}$ in the presence of SAILs and the results obtained from all various techniques matches very well. The mode of interaction of both SAILs with $\mathrm{Hb}$ is different. The observed results can be considered of special interest toward understanding of $\mathrm{Hb}$ -
SAILs colloidal chemistry as well as for designing formulations for industrial applications.

\section{Experimental}

\subsection{Materials}

Human hemoglobin as lyophilized powder, stored at $2-8{ }^{\circ} \mathrm{C}$ was purchased from Sigma Aldrich and used as received. The surface active ionic liquid, 1-dodecyl-3-methylimidazolium chloride $\left[\mathrm{C}_{12} \mathrm{mim}\right][\mathrm{Cl}]$ and 1-hexyl-3-methylimidazolium dodecylsulfate $\left[\mathrm{C}_{6} \mathrm{mim}\right][\mathrm{SDS}]$ were synthesized and characterized using ${ }^{1} \mathrm{H}$ NMR as per the procedures mentioned elsewhere. ${ }^{\mathbf{4 1 , 4 3}}$ The synthetic procedure of SAILs has been discussed in Annexure S1 of ESI $\dagger$ and the structures of the SAILs are given in Scheme 1. AR-grade potassium dihydrogen phosphate and dipotassium hydrogen phosphate were purchased from Merck, India. All the solutions used in the work were prepared in phosphate buffer ( $5 \mathrm{mM}$ and $\mathrm{pH}$ 6) using analytical balance with a precision of $\pm 0.0001 \mathrm{~g}$.

\subsection{Methods}

2.2.1. Surface tension measurements. The surface tension values $(\gamma)$ were measured using a Du Nouy ring tensiometer (Kruss Easy Dyne Tensiometer) from Kruss Gmbh (Hamburg, Germany) equipped with thermostat employing ring detachment method at $298.15 \mathrm{~K}$. The aqueous solution of $\left[\mathrm{C}_{12} \mathrm{mim}\right][\mathrm{Cl}]$ and $\left[\mathrm{C}_{6} \mathrm{mim}\right][\mathrm{SDS}]$ prepared in buffer were added into $\mathrm{Hb}$ solution and stirred for $2-3 \mathrm{~min}$ for complete mixing. The resultant solutions were kept for $5 \mathrm{~min}$ for equilibration prior to measurement. The data was collected thrice with accuracy \pm 0.1 $\mathrm{mN} \mathrm{m}{ }^{-1}$.

2.2.2. Fluorescence measurements. The steady state fluorescence measurements were performed on Hitachi F-4600 fluorescence spectrophotometer using a $10 \mathrm{~mm}$ path length quartz cuvette at $298.15 \pm 0.1 \mathrm{~K}$. The titrations were performed by adding concentrated stock solutions of $\left[\mathrm{C}_{12} \mathrm{mim}\right][\mathrm{Cl}]$ and $\left[\mathrm{C}_{6} \mathrm{mim}\right][\mathrm{SDS}]$ directly into the quartz cuvette containing $2 \mathrm{~mL}$ of $5 \mu \mathrm{M} \mathrm{Hb}$ solution. Changes in the intrinsic fluorescence of $\mathrm{Hb}$ were analyzed at an excitation wavelength $\left(\lambda_{\text {ex }}\right)$ of $280 \mathrm{~nm}$

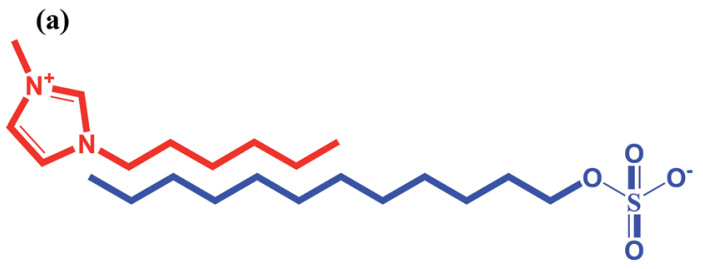

(b)

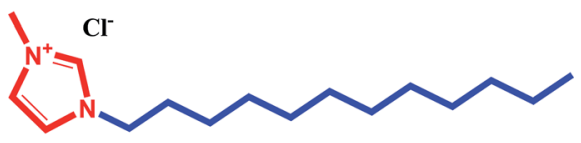

Scheme 1 Molecular structure of SAILs (a) 1-hexyl-3-methylimidazolium dodecylsulfate $\left[\mathrm{C}_{6} \mathrm{mim}\right][\mathrm{SDS}]$ and (b) 1-dodecyl-3methylimidazolium chloride $\left[\mathrm{C}_{12} \mathrm{mim}\right][\mathrm{Cl}]$ used in this study. 
and the emission spectra of $\mathrm{Hb}$ was recorded in the wavelength range of 300-500 $\mathrm{nm}$ wavelength.

2.2.3. UV-visible measurements. The absorption spectra were recorded on a UV-1800 Shimadzu UV-visible spectrophotometer with a quartz cuvette with a path length of $1 \mathrm{~cm}$. The absorbance of pure $\mathrm{Hb}$ in the presence and absence of $\left[\mathrm{C}_{12} \mathrm{mim}\right]$ $[\mathrm{Cl}]$ and $\left[\mathrm{C}_{6} \mathrm{mim}\right][\mathrm{SDS}]$ were recorded at $298.15 \mathrm{~K}$ in the range of $200-800 \mathrm{~nm}$.

2.2.4. Isothermal titration calorimetry (ITC) measurements. Calorimetric titrations were performed by using a MicroCal IT200 microcalorimeter at $298.15 \mathrm{~K}$. The sample cell was filled with $200 \mu \mathrm{L}$ of a solution of $5 \mu \mathrm{M} \mathrm{Hb}$ and the syringe was filled with $40 \mu \mathrm{L}$ of SAILs solutions and $2 \mu \mathrm{L}$ aliquots were added into cell. The parameters like time of addition and duration between each addition were monitored by the software provided with the instrument.

2.2.5. Dynamic light scattering (DLS) measurements. DLS measurements were carried out to determine the changes in the size of $\mathrm{Hb}$ upon interaction with $\left[\mathrm{C}_{12} \mathrm{mim}\right][\mathrm{Cl}]$ and $\left[\mathrm{C}_{6} \mathrm{mim}\right]$ [SDS] using Malvern NanoZS zeta-sizer equipped with $632.8 \mathrm{~nm}$ $\mathrm{He}-\mathrm{Ne}$ laser in backscattering mode at a scattering angle of $173^{\circ}$. The temperature $298.15 \mathrm{~K}$ was maintained by in-built temperature controller having an accuracy of $\pm 0.1 \mathrm{~K}$. All the samples prior to measurements were properly filtered from $0.2 \mu \mathrm{m}$ filters to avoid interference from dust particles.

2.2.6. Turbidity measurements. The turbidity measurements were performed on OAKTON T-100 turbidity meter. The sample cell was filled with $10 \mathrm{~mL} 5 \mu \mathrm{M}$ Hb solution and titrated with concentrated solution of SAILs with continuous stirring.

\section{Results and discussion}

\subsection{Surface tension measurements}

The tensiometry profiles of SAILs, $\left[\mathrm{C}_{6} \mathrm{mim}\right][\mathrm{SDS}]$ and $\left[\mathrm{C}_{12} \mathrm{mim}\right]$ $[\mathrm{Cl}]$ in the presence and absence of $5 \mu \mathrm{M} \mathrm{Hb}$ in buffer $(\mathrm{pH}$ 6.0) have been shown in Fig. 1(a) and (b) respectively. The $\gamma$ value decrease linearly for SAILs in buffer with increasing concentration of SAILs before reaching critical micelle concentration $(\mathrm{cmc})$ and after that a nearly constant value is obtained upto the completion of monolayer formation at $\gamma_{\mathrm{cmc}}$. The lower $\gamma_{\mathrm{cmc}}$ (27.1) value of $\left[\mathrm{C}_{6} \mathrm{mim}\right][\mathrm{SDS}]$ is an evidence that $\left[\mathrm{C}_{6} \mathrm{mim}\right][\mathrm{SDS}]$ is more densely packed and has better surface activity as compared to $\left[\mathrm{C}_{12} \mathrm{mim}\right][\mathrm{Cl}]\left(\gamma_{\mathrm{cmc}}=31.0\right)$. The marked decrease in $\mathrm{cmc}$ of $\left[\mathrm{C}_{6} \mathrm{mim}\right][\mathrm{SDS}]$ is due to the presence of both $\left[\mathrm{C}_{6} \mathrm{mim}\right]^{+}$ which provide hydrophobicity and 12 carbon long alkyl chain (SDS) as counterion which reduces the hydration and enhances counterion binding. The 6 carbon alkyl chain of $\left[\mathrm{C}_{6} \mathrm{mim}\right]^{+}$ interact with 12 carbon alkyl chain of anion via hydrophobic interactions similar to that of mixed micelles thus [ $\left.\mathrm{C}_{6} \mathrm{mim}\right]$ [SDS] possess lower cme value. ${ }^{42}$ The population of $\left[\mathrm{C}_{6} \mathrm{mim}\right]$ [SDS] is more at air-water interface due to effective screening offered by counterion between head groups, van der Waals interaction between alkyl chains of cation and anion along with $\mathrm{H}$-bond and electrostatic interaction between sulphate and imidazolium group. ${ }^{43}$ In the presence of $\mathrm{Hb}$, different tensiometric profiles were obtained for SAILs (shown in Fig. 1(a) and (b)). The $\gamma$ value for $\mathrm{Hb}$ was found to be low $\left(50 \mathrm{mN} \mathrm{m}^{-1}\right)$ which suggested that $\mathrm{Hb}$ is firmly surface active and get adsorbed at air-water interface. With successive addition of $\left[\mathrm{C}_{6} \mathrm{mim}\right][\mathrm{SDS}]$, $\gamma$ value decreases sharply upto $\mathrm{C}_{1}$ after that it decreases at a slow rate upto $\mathrm{C}_{2}$ followed by again steep decrease uptil $\mathrm{C}_{3}$ to attain saturation (Fig. 1(a)). Initially at lower concentration of [ $\left.\mathrm{C}_{6} \mathrm{mim}\right]$ [SDS] the sharp decrease in surface tension with lower slope indicates the initial complexation of $\left[\mathrm{C}_{6} \mathrm{mim}\right][\mathrm{SDS}]$ with $\mathrm{Hb}$ which leads to the formation of surface active $\mathrm{Hb}-\left[\mathrm{C}_{6} \mathrm{mim}\right][\mathrm{SDS}]$ monomer complex. At pH 6 (below isoelectric point) $\mathrm{Hb}$ display positive charge. The interactions are mainly electrostatic in nature in dilute concentration region as the positively charged $\left[\mathrm{C}_{6} \mathrm{mim}\right]^{+}$ions of SAIL interacts with negatively charged amino acid residues present on the protein along with the hydrophobic interactions between alkyl chain and hydrophobic moieties of $\mathrm{Hb}^{44}{ }^{44}$ After $\mathrm{C}_{1}$ the $\gamma$ value decreases slowly due to the formation of highly surface active $\mathrm{Hb}-\left[\mathrm{C}_{6} \mathrm{mim}\right][\mathrm{SDS}]$ monomer complexes which gets adsorbed and accumulated at air-water interface. After $\mathrm{C}_{2}$, further increase in concentrations of $\left[\mathrm{C}_{6} \mathrm{mim}\right][\mathrm{SDS}]$ sudden sharp decrease in $\gamma$ value has been observed. More
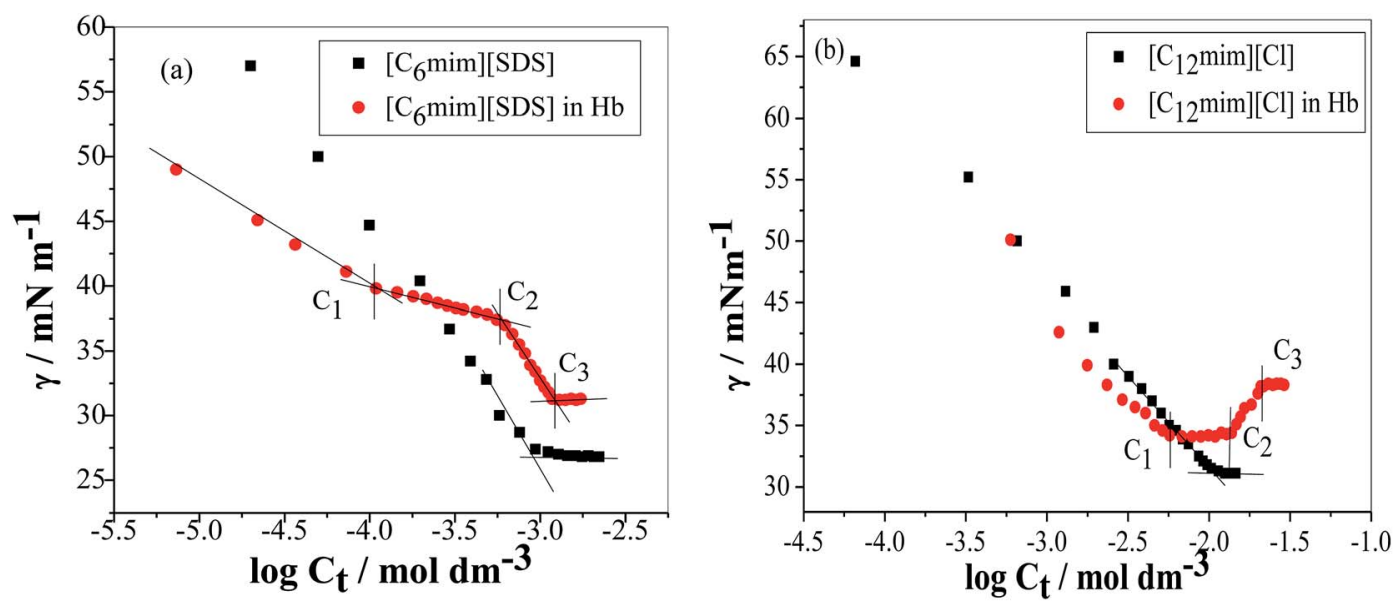

Fig. 1 Plots of surface tension $(\gamma)$ as a function of SAIL concentration in the absence and presence of $\mathrm{Hb}(5 \mu \mathrm{M})$ in PBS buffer (a) [C ${ }_{6}$ mim] [SDS] and (b) $\left[\mathrm{C}_{12} \mathrm{mim}\right][\mathrm{Cl}]$. 
added $\left[\mathrm{C}_{6} \mathrm{mim}\right][\mathrm{SDS}]$ occupy free sites at interface thus reduces $\gamma$ up to $\mathrm{C}_{3}$. In region $\mathrm{C}_{2}-\mathrm{C}_{3} \mathrm{Hb}$ undergoes conformational changes and $\mathrm{Hb}-\left[\mathrm{C}_{6} \mathrm{mim}\right][\mathrm{SDS}]$ monomer complex transformed into $\mathrm{Hb}-\left[\mathrm{C}_{6} \mathrm{mim}\right][\mathrm{SDS}]$ aggregates complex. The formation of highly surface active $\mathrm{Hb}-\left[\mathrm{C}_{6} \mathrm{mim}\right][\mathrm{SDS}]$ aggregate complex is driven by electrostatic interactions though the role of hydrophobic interactions between alkyl chain of $\left[\mathrm{C}_{6} \mathrm{mim}\right][\mathrm{SDS}]$ and hydrophobic parts of $\mathrm{Hb}$ cannot be ruled out. Some earlier reports have also suggested the formation of complexes between proteins and ionic liquids. ${ }^{45-47}$ After $\mathrm{C}_{3}$, more addition of $\left[\mathrm{C}_{6} \mathrm{mim}\right][\mathrm{SDS}]$ does not change $\gamma$ value and saturation arises due to the formation of free micelles along with $\mathrm{Hb}-\left[\mathrm{C}_{6} \mathrm{mim}\right]$ [SDS] aggregates. Various interfacial and thermodynamic parameters such as surface excess concentration $\left(\tau_{\max }\right)$, minimum area per molecule $\left(A_{\mathrm{min}}\right)$, surface pressure $\left(\pi_{\mathrm{cmc}}\right)$, standard Gibb's free energy of micellization $\left(\Delta G_{\mathrm{m}}^{\circ}\right)$ and standard Gibb's free energy of adsorption $\left(\Delta G_{\text {ads }}^{\circ}\right)$ were evaluated using relevant equations (Annexure SII of ESI $\dagger$ ) and provided in Table 1 . The $\tau_{\max }$ value for $\mathrm{Hb}+\left[\mathrm{C}_{6} \mathrm{mim}\right][\mathrm{SDS}]$ system is higher in comparison to $\mathrm{Hb}$ free $\left[\mathrm{C}_{6} \mathrm{mim}\right][\mathrm{SDS}]$ system which implies that mixture has better surface activity than pure $\left[\mathrm{C}_{6} \mathrm{mim}\right][\mathrm{SDS}]$. As expected opposite trend has been observed in $A_{\text {min }}$ values indicating the better compactness due to densely packed molecules in the presence of $\mathrm{Hb}$ as compared in buffer. The negative values of both $\Delta G_{\mathrm{m}}^{\circ}$ and $\Delta G_{\mathrm{ads}}^{\circ}$ clearly indicates the feasibility of both micellization and adsorption phenomenon.

In case of $\mathrm{Hb}+\left[\mathrm{C}_{12} \mathrm{mim}\right][\mathrm{Cl}]$ system the behaviour of $\gamma$ is quite different as compared to $\mathrm{Hb}+\left[\mathrm{C}_{6} \mathrm{mim}\right][\mathrm{SDS}]$ system. As clear from Fig. 1 (b) the $\gamma$ value of $\left[\mathrm{C}_{12} \mathrm{mim}\right][\mathrm{Cl}]$ in buffer decreases linearly and showed a minima near cmc after that $\gamma$ attain constant region. Whereas in the presence of $\mathrm{Hb}$ tensiometric profile exhibit three breaks points owing to $\mathrm{Hb}-$ $\left[\mathrm{C}_{12} \mathrm{mim}\right][\mathrm{Cl}]$ interactions. Initially at low concentration of $\left[\mathrm{C}_{12} \mathrm{mim}\right][\mathrm{Cl}], \gamma$ decreases sharply upto $\mathrm{C}_{1}$ due to the formation of surface active $\mathrm{Hb}-\left[\mathrm{C}_{12} \mathrm{mim}\right][\mathrm{Cl}]$ monomer complex at interface owing to the presence of mainly electrostatic interactions along with hydrophobic interactions. The change in slope is less in $\mathrm{Hb}-\left[\mathrm{C}_{12} \mathrm{mim}\right][\mathrm{Cl}]$ system when compared to $\mathrm{Hb}-\left[\mathrm{C}_{6} \mathrm{mim}\right]$ [SDS] system indicating the presence of more stronger electrostatic interactions in $\left[\mathrm{C}_{12} \mathrm{mim}\right][\mathrm{Cl}]$ monomers and $\mathrm{Hb}$. In region $\mathrm{C}_{1}-\mathrm{C}_{2}$ a plateau region is formed. It must be considered that beginning concentrations of plateau is the region where $\mathrm{Hb}-$ $\left[\mathrm{C}_{12} \mathrm{mim}\right][\mathrm{Cl}]$ monomer complex starts to transform into $\mathrm{Hb}-$ $\left[\mathrm{C}_{12} \mathrm{mim}\right][\mathrm{Cl}]$ aggregate complex and ending concentration is the region where the aggregates continued to bind with protein sites that restrict the transfer of SAILs molecules to the interface to maintain constant $\gamma$ value. Guillot et al. has reported the formation of flat region in the aqueous solution of a polyelectrolyte, carboxymethylcellulose, and a cationic surfactant, dodecyltrimethylammonium bromide (DTAB). ${ }^{48}$ On reaching $\mathrm{C}_{2}$ the formed aggregate complex collapsed and invaded into bulk from interface which leads to rise in $\gamma$ value to maximum. Above $\mathrm{C}_{3} \gamma$ remains almost constant and further addition of SAIL leads to the formation of free micelles. The calculated interfacial and thermodynamic parameters for $\left[\mathrm{C}_{12} \mathrm{mim}\right][\mathrm{Cl}]$ in the absence and presence of $\mathrm{Hb}$ have also been computed and given in Table 1 . The lower $\tau_{\max }$ and higher $A_{\min }$ of $\left[\mathrm{C}_{12} \mathrm{mim}\right][\mathrm{Cl}]$ as compared to $\left[\mathrm{C}_{6} \mathrm{mim}\right][\mathrm{SDS}]$ indicates the lower surface activity of $\left[\mathrm{C}_{12} \mathrm{mim}\right][\mathrm{Cl}]$. For $\mathrm{Hb}-\left[\mathrm{C}_{12} \mathrm{mim}\right][\mathrm{Cl}]$ system, there is no slope change prior to reach cmc $\left(\mathrm{C}_{2}\right)$ hence $\tau_{\max }$ and $A_{\text {min }}$ values were not determined for mixture. The more negative value of $\Delta G_{\mathrm{m}}^{\circ}$ in pure SAILs solutions when compared to $\mathrm{Hb}$-SAIL system indicate the greater feasibility of micellization of SAILs in the absence of $\mathrm{Hb}$. The value of various transition concentrations $\left(\mathrm{C}_{1}, \mathrm{C}_{2}\right.$ and $\left.\mathrm{C}_{3}\right)$ for $\mathrm{Hb}-\left[\mathrm{C}_{6} \mathrm{mim}\right][\mathrm{SDS}] /\left[\mathrm{C}_{12} \mathrm{mim}\right][\mathrm{Cl}]$ system observed from different techniques are given in Table 2 .

\subsection{Spectroscopic study (UV-vis absorption and fluorescence measurements)}

To study the change in protein conformation upon binding with ligands UV-vis spectroscopy and fluorescence spectroscopy methods are good to be adopted. ${ }^{\mathbf{4 9 , 5 0}}$ Both are very simple but efficacious techniques to analyze the binding of SAILs $\left[\mathrm{C}_{12} \mathrm{mim}\right][\mathrm{Cl}]$ and $\left[\mathrm{C}_{6} \mathrm{mim}\right][\mathrm{SDS}]$ with $\mathrm{Hb}$. The isoelectric point of $\mathrm{Hb}$ is 6.8 and we have studied the interaction of SAILs with

Table 2 The various transition concentrations $\left(\mathrm{mmol} \mathrm{dm}^{-3}\right)$ observed from different techniques: surface tension (ST), fluorescence measurements (Flu), UV-visible measurements (UV), DLS measurements and turbidity measurements in $\mathrm{Hb}-\left[\mathrm{C}_{6}\right.$ mim] [SDS] and $\mathrm{Hb}-$ $\left[\mathrm{C}_{12} \operatorname{mim}\right][\mathrm{Cl}]$

\begin{tabular}{|c|c|c|c|c|c|}
\hline Concentration (mM) & ST & Flu & UV & DLS & Turbid \\
\hline \multicolumn{6}{|l|}{$\mathrm{Hb}-\left[\mathrm{C}_{6} \mathrm{mim}\right][\mathrm{SDS}]$} \\
\hline $\mathrm{C}_{1}$ & 0.11 & 0.13 & 0.10 & 0.13 & 0.11 \\
\hline $\mathrm{C}_{2}$ & 0.61 & 0.72 & 0.63 & 0.66 & 0.62 \\
\hline $\mathrm{C}_{3}$ & 1.25 & 1.27 & 1.43 & 1.10 & 1.18 \\
\hline \multicolumn{6}{|l|}{$\mathrm{Hb}-\left[\mathrm{C}_{12} \mathrm{mim}\right][\mathrm{Cl}]$} \\
\hline $\mathrm{C}_{1}$ & 6.10 & 4.40 & 2.90 & 3.60 & 5.60 \\
\hline $\mathrm{C}_{2}$ & 13.3 & 12.00 & 11.90 & 11.00 & 10.80 \\
\hline $\mathrm{C}_{3}$ & 21.20 & 19.20 & - & 21.30 & 19.20 \\
\hline
\end{tabular}

Table 1 Interfacial and thermodynamic parameters: surface tension at $\mathrm{cmc}\left(\gamma_{\mathrm{cmc}}\right)$, surface pressure at $\mathrm{cmc}\left(\pi_{\mathrm{cmc}}\right)$, surface excess $\left(\Gamma_{\text {max }}\right)$ and minimum area per molecule $\left(A_{\text {min }}\right)$, Gibbs free energy of micellization $\left(\Delta G_{\mathrm{m}}^{\circ}\right)$ and Gibbs free energy of adsorption $\left(\Delta G_{\text {ads }}^{\circ}\right)$ for $\mathrm{Hb}-\left[\mathrm{C}_{6} \mathrm{mim}\right]$ [SDS] and $\mathrm{Hb}-\left[\mathrm{C}_{12} \mathrm{mim}\right][\mathrm{Cl}]$ systems

\begin{tabular}{|c|c|c|c|c|c|c|c|}
\hline System & $\mathrm{cmc}(\mathrm{mM})$ & $\gamma_{\mathrm{cmc}}\left(\mathrm{mN} \mathrm{m}^{-1}\right)$ & $\pi_{\mathrm{cmc}}\left(\mathrm{mN} \mathrm{m}^{-1}\right)$ & $10^{6} \tau_{\max }\left(\mathrm{mol} \mathrm{m}^{-2}\right)$ & $A_{\min }(\AA)^{2}$ & $\Delta G_{\mathrm{m}}^{\circ}\left(\mathrm{kJ} \mathrm{mol}^{-1}\right)$ & $\Delta G_{\mathrm{ads}}^{\circ}\left(\mathrm{kJ} \mathrm{mol}^{-1}\right)$ \\
\hline$\left[\mathrm{C}_{6} \mathrm{mim}\right][\mathrm{SDS}]$ & 0.98 & 27.1 & 42.9 & 3.13 & 53.04 & -27.12 & -40.84 \\
\hline$\left[\mathrm{C}_{12} \mathrm{mim}\right][\mathrm{Cl}]$ & 11.00 & 31.3 & 38.6 & 2.71 & 61.26 & -21.13 & -35.38 \\
\hline $\mathrm{Hb}-\left[\mathrm{C}_{6} \mathrm{mim}\right][\mathrm{SDS}]$ & 1.25 & 31.1 & 19.0 & 3.69 & 44.99 & -26.52 & -31.66 \\
\hline $\mathrm{Hb}-\left[\mathrm{C}_{12} \mathrm{mim}\right][\mathrm{Cl}]$ & 13.30 & 34.3 & 15.7 & - & - & -20.65 & - \\
\hline
\end{tabular}


$\mathrm{Hb}$ at $\mathrm{pH} 6$ where $\mathrm{Hb}$ displays positive charge. The UV-vis spectra of $\mathrm{Hb}$ shows several peaks, one at $276 \mathrm{~nm}$ due to phenyl group of Trp and tyrosine residue, $406 \mathrm{~nm}$ (Soret band, due to $\pi \rightarrow \pi^{*}$ transition), 500, 536, 576 and $630 \mathrm{~nm}$ (due to oxy band or $\mathrm{Q}$ band and ligand to metal charge transfer spectra). The allowed $\pi \rightarrow \pi^{*}$ transitions are mainly due to heme group of protein which is embedded in the hydrophobic pocket formed by protein backbone. ${ }^{51}$ Thus appearance of Soret band at $405 \mathrm{~nm}$ confirms the folded or native structure of $\mathrm{Hb}$. Any disturbance or changes in Soret band reveals the reduction in $\alpha$-helix content of $\mathrm{Hb}^{52}$ Fig. 2(a) and (b) shows the UV-vis absorption spectra of $\mathrm{Hb}$ with increasing concentration of $\left[\mathrm{C}_{6} \mathrm{mim}\right][\mathrm{SDS}]$ and $\left[\mathrm{C}_{12} \mathrm{mim}\right][\mathrm{Cl}]$ respectively whereas Fig. 3(a) and (b) shows the variation of absorption as a function of SAILs concentration. The expanded region considering the absorbance peaks at 495, 535, 575 and $630 \mathrm{~nm}$ have been shown in Fig. S2(a) and (b) in ESI. $\dagger$ With the addition of $\left[\mathrm{C}_{6} \mathrm{mim}\right][\mathrm{SDS}]$, absorption peak of Soret band at $405 \mathrm{~nm}$ decreases linearly up to $\mathrm{C}_{1}$ without any shift in $\lambda_{\max }$ (Fig. S3 $\dagger$ ). These results indicates that initially $\left[\mathrm{C}_{6} \mathrm{mim}\right][\mathrm{SDS}]$ interact with backbone of $\mathrm{Hb}$ through weak electrostatic interactions, hydrogen bonding and hydrophobic interactions. Once the $\mathrm{C}_{1}$ reached, the turbidity appears which results into increment of UV-vis absorption upto $\mathrm{C}_{1}^{\prime}$ followed by decrement upto $\mathrm{C}^{\prime \prime}{ }_{1}$. The appearance of turbidity is the result of charge neutralisation of oppositely charged $\left[\mathrm{C}_{6} \mathrm{mim}\right][\mathrm{SDS}]$ and amino acid residues of $\mathrm{Hb}$. Once the $\mathrm{C}_{1}$ reached, the $\lambda_{\max }$ also shifts and a new peak starts to form at $415 \mathrm{~nm}$, the main characteristic of hemichrome. ${ }^{53}$ The formation of new band at $415 \mathrm{~nm}$ clearly indicates the oxidation of oxyhemoglobin to methemoglobin (metHb) and latter converted into hemichrome. ${ }^{54}$ The autooxidation process is not a simple but it is associated with the dissociative mechanism with the loss of superoxide anion $\left(\mathrm{O}_{2}{ }^{-}\right)$from oxyHb and leads to the formation of 5-coordinated intermediate. This vacant position in 5-coordinated $\mathrm{Fe}^{3+}$ complex is thus occupied by either hydroxyl ion or by water molecules (from surrounding medium) to form metHb. ${ }^{55}$ But in the presence of surface active ionic liquids the metHb gets converted to hemichrome. The potentiality of interactions present between $\mathrm{Hb}$ and SAILs bring a comprehensive change in surrounding environment of
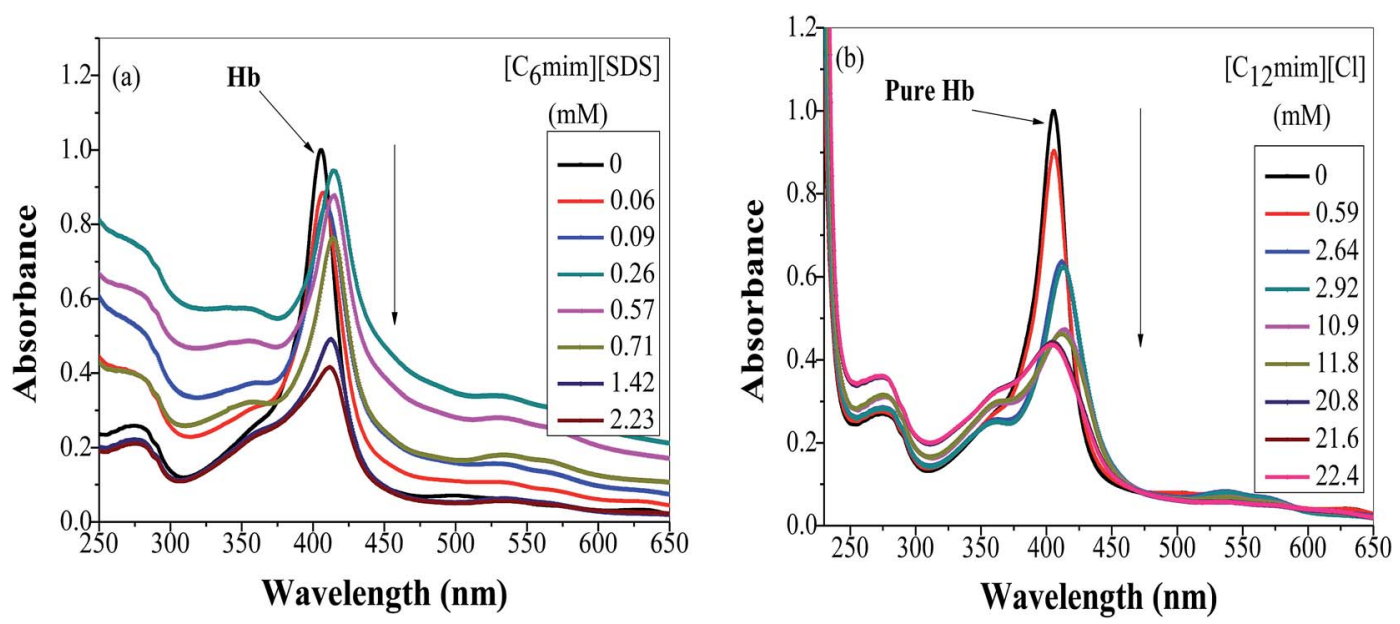

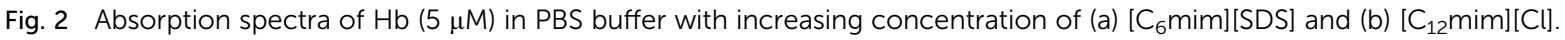
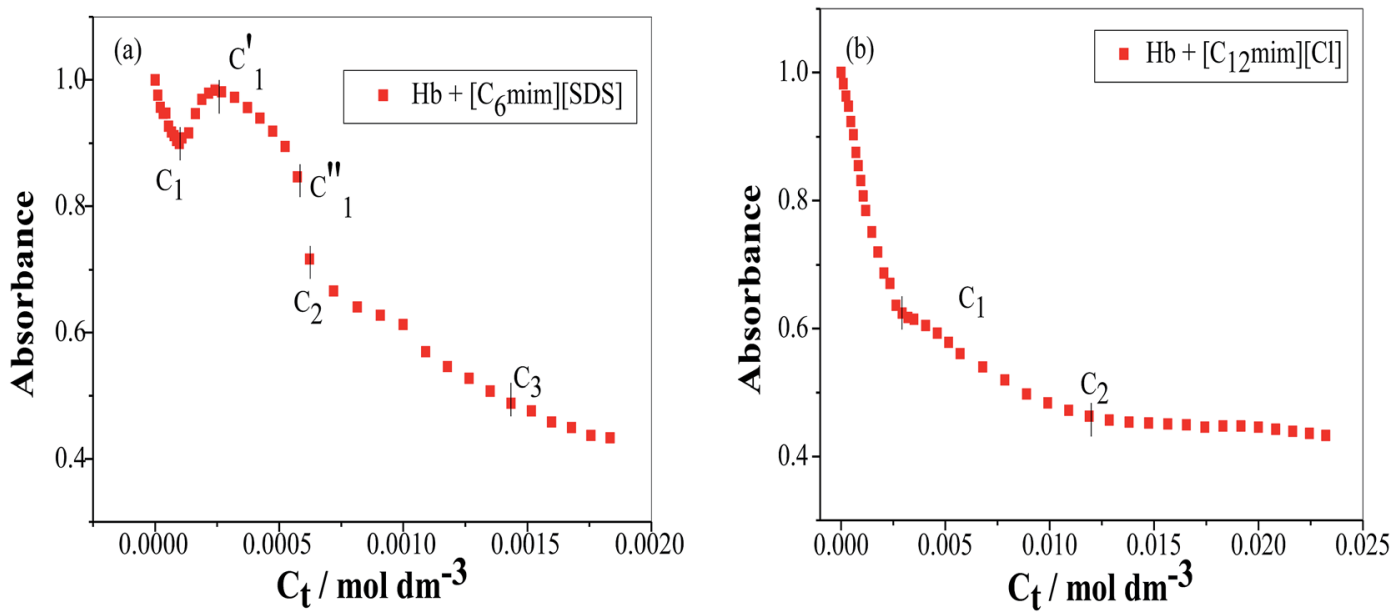

Fig. 3 Variation of absorbance (at $\lambda_{\max }$ ) as a function of SAIL concentration for (a) $\left[\mathrm{C}_{6} \mathrm{mim}\right][\mathrm{SDS}]$ and $(\mathrm{b})\left[\mathrm{C}_{12} \mathrm{mim}\right][\mathrm{Cl}]$. 
the heme pocket and induce the conversion of metHb to hemichrome by breaking hydrogen bond between distal histidine imidazole and water molecule/hydroxyl ions. With increasing concentration of $\left[\mathrm{C}_{6} \mathrm{mim}\right][\mathrm{SDS}]$ after $\mathrm{C}_{2}$ the absorption decreases but $\lambda_{\max }$ remains unchanged unlike $\mathrm{Hb}$ $\left[\mathrm{C}_{12} \mathrm{mim}\right][\mathrm{Cl}]$ system (discussed ahead) which reveals that addition of more $\left[\mathrm{C}_{6} \mathrm{mim}\right][\mathrm{SDS}]$ leads to formation of $\left[\mathrm{C}_{6} \mathrm{mim}\right]$ [SDS]-Hb aggregates via strong electrostatic and hydrophobic interactions. With careful observation it was observed that turbidity appears only upto $\mathrm{C}^{\prime \prime}{ }_{1}$ after that it disappears with sharp linear decrement in UV-vis absorption upto $\mathrm{C}_{2}$. The disappearance of turbidity clearly indicates that when $\mathrm{C}_{2}$ reached the hydrophobic interactions between hydrophobic tail of $\left[\mathrm{C}_{6} \mathrm{mim}\right][\mathrm{SDS}]$ and $\mathrm{Hb}$ dominates over the electrostatic interactions and they stabilized the hemichrome formation. These results were contrary to earlier reported Hb-SDS system where SDS micelles induce the heme release and solubilise them in micellar core whereas in $\left[\mathrm{C}_{6} \mathrm{mim}\right][\mathrm{SDS}]$ molecules the long hydrophobic chain forms network like structure thus prevent the release of heme molecules. ${ }^{56}$ These results were also confirmed from the changes in the fluorescence intensity upon addition of $\left[\mathrm{C}_{6} \mathrm{mim}\right][\mathrm{SDS}]$ as shown in Fig. 4(a). The fluorescence of proteins arises from Trp, tyrosine and phenylalanine present in protein. In hemoglobin the intrinsic fluorescence primarily arises from 3 Trp residues ( $\alpha 214$ Trp, $\beta 215$ Trp and $\beta 216$ Trp). ${ }^{57}$ The hemoglobin exhibit weak fluorescence due to the quenching of Trp fluorescence by heme group of porphyrin ring by radiationless energy transfer. ${ }^{58}$ In presence of $\left[\mathrm{C}_{6} \mathrm{mim}\right][\mathrm{SDS}]$ the fluorescence intensity of $\mathrm{Hb}$ increases might be because of two main reasons. First, is the increased hydrophobicity around heme group and second could be the prevention of quenching effect owing to nonradiative energy transfer from Trp residue to heme group. The heme group is initially embedded in the hydrophobic cavity of the protein but with the addition of SAIL the hydrophobic tail of $\left[\mathrm{C}_{6} \mathrm{mim}\right][\mathrm{SDS}]$ penetrate into hydrophobic cavity of $\mathrm{Hb}$ and heme group is exposed which leads to the fluorescence enhancement. The fluorescence intensity increase slowly upto
$\mathrm{C}_{1}$ which indicates the presence of interactions between $\mathrm{Hb}$ $\left[\mathrm{C}_{6} \mathrm{mim}\right][\mathrm{SDS}]$. After $\mathrm{C}_{1}$ the fluorescence intensity increases and mixture become turbid indicates that $\mathrm{Hb}-\left[\mathrm{C}_{6} \mathrm{mim}\right][\mathrm{SDS}]$ aggregates formed owing to strong electrostatic interactions between oppositely charged groups but once $\mathrm{C}_{2}$ reached turbidity disappears and blue shift in $\lambda_{\max }$ have also been observed. The fluorescence intensity sharply increases after $\mathrm{C}_{2}$ and continues to increase uptil $\mathrm{C}_{3}$ reached after which saturation comes. These results reveal that after the disappearance of turbidity hydrophobic interactions dominates over electrostatic interactions. The unchanged $\lambda_{\max }$ suggest that hemichrome is not further changed and stabilized by $\left[\mathrm{C}_{6} \mathrm{mim}\right][\mathrm{SDS}]$ micelles. The sharp rise in fluorescence intensity is up to $\mathrm{C}_{3}$ after that it becomes constant as free micelles formed and $\mathrm{Hb}$ surface get saturated with formed micelles. As the turbid nature of $\mathrm{Hb}-\left[\mathrm{C}_{6} \mathrm{mim}\right][\mathrm{SDS}]$ solution was monitored by naked eye hence turbidity measurements were further performed. The variation of turbidity of $\mathrm{Hb}$ as a function of concentration of $\left[\mathrm{C}_{6} \mathrm{mim}\right][\mathrm{SDS}]$ and $\left[\mathrm{C}_{12} \mathrm{mim}\right][\mathrm{Cl}]$ has been provided as Fig. $\mathrm{S} 4(\mathrm{a})$ and $(\mathrm{b}) \dagger$ respectively and the transitions extracted from the plot matches well with the transitions obtained from other techniques.

The UV-vis and variation in fluorescence intensity plot of $\mathrm{Hb}$ in the presence of $\left[\mathrm{C}_{12} \mathrm{mim}\right][\mathrm{Cl}]$ show different results as shown in Fig. 2(b), 3(b) and 4(b). The fluorescence emission spectra of $\mathrm{Hb}$ with varying concentration of $\left[\mathrm{C}_{12} \mathrm{mim}\right][\mathrm{Cl}]$ has been shown as Fig. S5. $\dagger$ As shown in Fig. 2(b) and 3(b) the absorption of Soret band of $\mathrm{Hb}$ decreases linearly upto $\mathrm{C}_{1}$ without any change shift in $\lambda_{\max }$ indicates that initially $\left[\mathrm{C}_{12} \mathrm{mim}\right][\mathrm{Cl}]$ interact with $\mathrm{Hb}$ via weak forces. The decrease in absorption is continues upto $\mathrm{C}_{1}$ after that the decrement in absorption peak get slow. When the concentration of $\left[\mathrm{C}_{12} \mathrm{mim}\right][\mathrm{Cl}]$ reached above $\mathrm{C}_{1}$ the absorption of Soret band decreases gently along with red shift from $405 \mathrm{~nm}$ to $413 \mathrm{~nm}$. This change in Soret band after $\mathrm{C}_{1}$ confirms that geometric distortion arise due to dielectric and electrostatic interactions of proteins and changes the symmetry in heme environment. These results were also in accordance with the fluorescence measurements results
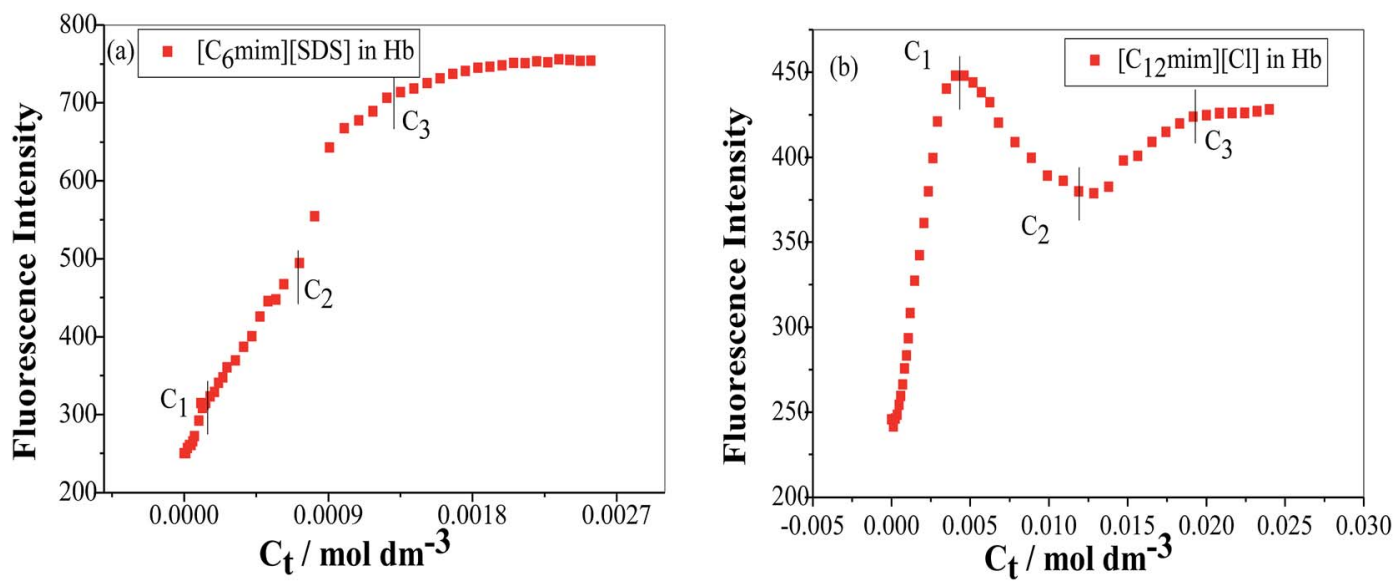

Fig. 4 Variation of fluorescence emission intensity of $\mathrm{Hb}(5 \mu \mathrm{M})$ in PBS buffer as a function of SAIL concentration for (a) [C ${ }_{6}$ mim] [SDS] and (b) $\left[\mathrm{C}_{12} \mathrm{mim}\right][\mathrm{Cl}]$ when excited at $280 \mathrm{~nm}$. 
(Fig. 4(b)) where at lower concentration of $\left[\mathrm{C}_{12} \mathrm{mim}\right][\mathrm{Cl}]$ (below $\mathrm{C}_{1}$ ) the fluorescence intensity of $\mathrm{Hb}$ increases which has been attributed to conformational changes in $\mathrm{Hb}$ on interacting with SAIL molecules. On partial unfolding of $\mathrm{Hb}$, the distance between Trp residue and heme group is increased which shield the nonradiative energy transfer from Trp to heme moiety. With further increasing $\left[\mathrm{C}_{12} \mathrm{mim}\right][\mathrm{Cl}]$ concentration the intensity decreases due to the formation of $\mathrm{Hb}-\left[\mathrm{C}_{12} \mathrm{mim}\right][\mathrm{Cl}]$ aggregate complex guided by enhanced hydrophobic interactions between $\left[\mathrm{C}_{12} \mathrm{mim}\right][\mathrm{Cl}]$ tail and hydrophobic moieties of $\mathrm{Hb}$. After $\mathrm{C}_{2}$ addition of more $\left[\mathrm{C}_{12} \mathrm{mim}\right][\mathrm{Cl}]$ increases fluorescence intensity due to increased hydrophobicity around heme group and then reaches upto $\mathrm{C}_{3}$ after that the addition of more SAIL leads to the saturation of $\mathrm{Hb}$ in aqueous medium. Whereas in case of UV-vis, once $\mathrm{C}_{2}$ reached the absorbance decreases very slightly but blue shift of Soret band has been observed, latter shifts from $413 \mathrm{~nm}$ to $404 \mathrm{~nm}$. The transitions in $\lambda_{\max }$ of Soret band from $405 \mathrm{~nm}$ to $413 \mathrm{~nm}$ and from $413 \mathrm{~nm}$ to $404 \mathrm{~nm}$ at higher concentration of $\left[\mathrm{C}_{12} \mathrm{mim}\right][\mathrm{Cl}]$ indicate the transformation of aquometHb to hemichrome and hemichrome to heme monomer respectively. ${ }^{56}$ Such blue shift (413 $\mathrm{nm}$ to $404 \mathrm{~nm}$ ) of Soret band in $\left[\mathrm{C}_{12} \mathrm{mim}\right][\mathrm{Cl}]-\mathrm{Hb}$ system which is absent in $\left[\mathrm{C}_{6} \mathrm{mim}\right][\mathrm{SDS}]-\mathrm{Hb}$ system illustrate the formation of pentacoordinated heme and also get confirmed from the appearance of new absorption peak at $575 \mathrm{~nm}$ at higher concentration of $\left[\mathrm{C}_{12} \mathrm{mim}\right][\mathrm{Cl}] .{ }^{8}$ Similar type of behaviour of hemoproteins in the presence of surfactants has been exemplified earlier as well. ${ }^{\mathbf{5 9 6 0}}$ At higher concentration free micelles of $\left[\mathrm{C}_{12} \mathrm{mim}\right][\mathrm{Cl}]$ formed which induce the heme group to be released from the hydrophobic pocket of protein, probably because the hydrophobic cavity of $\left[\mathrm{C}_{12} \mathrm{mim}\right][\mathrm{Cl}]$ can solubilise heme.

Based on the above discussion we can understand that the two main processes were carried out by SAILs with their addition to $\mathrm{Hb}$ (a) dissociation of $\mathrm{Hb}$ subunits which leads to the exposure of amino acids residues involved in inter-subunit connections (b) the oxidation of ferrous state of metallic centre to ferric state. The spectral changes observed for SAILs are different. The $\left[\mathrm{C}_{6} \mathrm{mim}\right][\mathrm{SDS}]$ monomers binds strongly to $\mathrm{Hb}$ as compared to $\left[\mathrm{C}_{12} \mathrm{mim}\right][\mathrm{Cl}]$ owing to the presence of strong electrostatic interactions and hydrophobic interactions in $\left[\mathrm{C}_{6} \mathrm{mim}\right][\mathrm{SDS}]-\mathrm{Hb}$ system which can also justified on the basis of binding constant and ITC measurements (discussed ahead). The $\left[\mathrm{C}_{6} \mathrm{mim}\right][\mathrm{SDS}]$ initially form monomer complex with $\mathrm{Hb}$ and brings conformational changes of $\mathrm{Hb}$ in term of unfolding. They transform the aqomethHb to hemichrome and stabilize the hemichrome whereas in $\left[\mathrm{C}_{12} \mathrm{mim}\right][\mathrm{Cl}]-\mathrm{Hb}$ system conformational changes arises due to transformation of aqomethHb to hemichrome and hemichrome is further transformed into heme monomer which is solubilised in the $\left[\mathrm{C}_{12} \mathrm{mim}\right][\mathrm{Cl}]$ micellar core. The long hydrophobic chain of $\left[\mathrm{C}_{6} \mathrm{mim}\right][\mathrm{SDS}]$ interacts with two hydrophobic regions of $\mathrm{Hb}$ and it can form a network like structure which prevent heme group to leave the protein cavity. But the complex structure of $\left[\mathrm{C}_{6} \mathrm{mim}\right][\mathrm{SDS}]$ brings conformational changes and also disrupts the environment around heme group.

\subsection{Quantitative evaluation of Hb-SAILs interaction}

In view of tensiometry, UV-vis spectroscopy and fluorescence measurements it was concluded that at lower concentration of SAILs (before $\mathrm{C}_{1}$ ) $\mathrm{Hb}-\left[\mathrm{C}_{6} \mathrm{mim}\right][\mathrm{SDS}]$ and $\mathrm{Hb}-\left[\mathrm{C}_{12} \mathrm{mim}\right][\mathrm{Cl}]$ monomer complex were formed and guided by electrostatic and hydrophobic interactions. Thus for quantitative estimation of the binding of SAILs to the $\mathrm{Hb}$ the absorbance data is used in the Benesi-Hildebrand equation which is given as follows ${ }^{\mathbf{6 1}}$

$$
\frac{1}{A_{\mathrm{o}}-A}=\frac{1}{K_{\mathrm{a}}\left(A_{1}-A_{\mathrm{o}}\right)[\mathrm{SAIL}]^{n}}+\frac{1}{A_{1}-A_{\mathrm{o}}}
$$

where $A_{\mathrm{o}}, A$ and $A_{1}$ are the absorbance in the absence, at intermediate $\mathrm{Hb}$-SAILs complex concentration and at infinite concentration of SAILs respectively and $K_{\mathrm{a}}$ is the binding constant. The plot of $1 / A-A_{\mathrm{o}}$ versus $1 /[\mathrm{SAIL}]^{n}$ gives straight line when $n=1$ indicating $1: 1$ stoichiometry for these complexes (Fig. 5). The stoichiometry was further confirmed using Job's plot (discussed in Annexure SIII $\dagger$ ). The binding constant further used to calculate free energy change $(\Delta G)$ for $\mathrm{Hb}-\left[\mathrm{C}_{6} \mathrm{mim}\right][\mathrm{SDS}]$ and $\mathrm{Hb}-\left[\mathrm{C}_{12} \mathrm{mim}\right][\mathrm{Cl}]$ complexes using eqn (2) and provided in Table 3 .

$$
\Delta G=-R T \ln K_{\mathrm{a}}
$$

where $R$ and $T$ are universal gas constant and temperature respectively. It can be observed from the $K_{\mathrm{a}}$ values that binding constant is stronger for $\left[\mathrm{C}_{6} \mathrm{mim}\right][\mathrm{SDS}]+\mathrm{Hb}$ system as compared to $\left[\mathrm{C}_{12} \mathrm{mim}\right][\mathrm{Cl}]$ due to difference in their hydrophobicity. It must be kept in mind that the binding constant determined from $\mathrm{B}-\mathrm{H}$ equation gives the quantitative detail of interactions present in monomer region only. Thus in Hb-SAIL monomer complex both electrostatic and hydrophobic forces are present, but electrostatic forces are strong in $\mathrm{Hb}-\left[\mathrm{C}_{6} \mathrm{mim}\right][\mathrm{SDS}]$ system as compared to $\mathrm{Hb}-\left[\mathrm{C}_{12} \mathrm{mim}\right][\mathrm{Cl}]$ system. The negative value of $\Delta G$ indicates the feasibility and spontaneity of $\mathrm{Hb}$-SAILs complex formation.

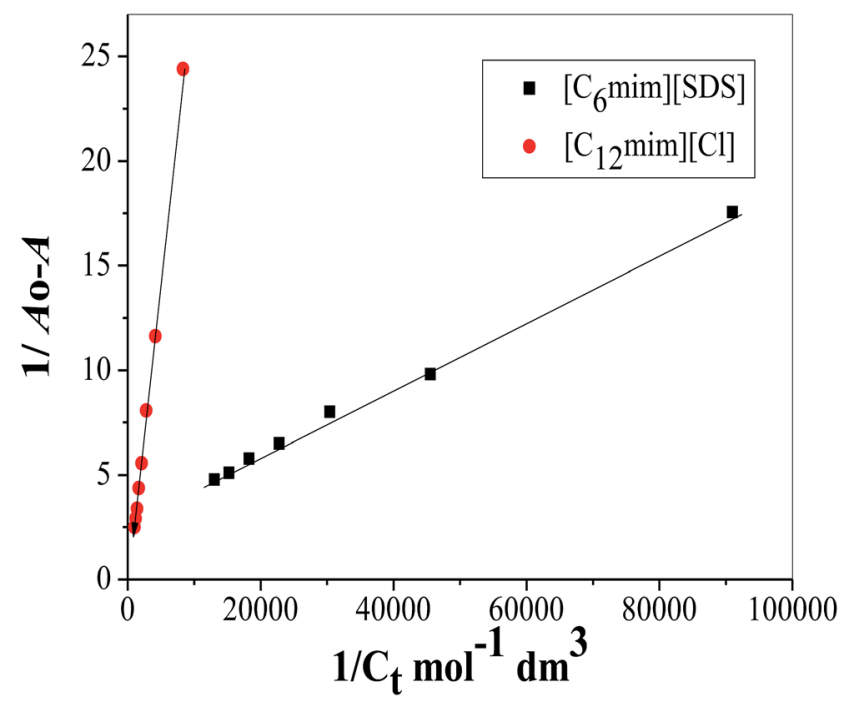

Fig. 5 Benesi-Hildebrand plot for binding constant determination using changes in absorption spectra of $\mathrm{Hb}(5 \mu \mathrm{M})$ in the presence of varying concentration of SAILs. 
Table 3 Estimated binding constant $\left(K_{\mathrm{a}}\right)$, Gibbs free energy change $(\Delta G)$ and correlation coefficients $\left(R_{\mathrm{c}}\right)$ for $\mathrm{Hb}-\left[\mathrm{C}_{6}\right.$ mim] [SDS] and $\mathrm{Hb}-$ $\left[\mathrm{C}_{12}\right.$ mim] $[\mathrm{Cl}]$ systems from UV-visible measurements

\begin{tabular}{llll}
\hline System & $\begin{array}{l}K_{\mathrm{a}} \\
\left(\times 10^{3} \mathrm{M}^{-1}\right)\end{array}$ & $\begin{array}{l}\Delta G \\
\left(\mathrm{~kJ} \mathrm{~mol}^{-1}\right)\end{array}$ & $R_{\mathrm{c}}$ \\
\hline $\mathrm{Hb}-\left[\mathrm{C}_{6} \mathrm{mim}\right][\mathrm{SDS}]$ & 16.93 & -24.13 & 0.9989 \\
$\mathrm{Hb}-\left[\mathrm{C}_{12} \mathrm{mim}\right][\mathrm{Cl}]$ & 0.22 & -13.40 & 0.9997
\end{tabular}

\subsection{Isothermal titration calorimetry (ITC) measurements}

The ITC experiments were performed further to explain the enthalpy changes in binding of $\mathrm{Hb}$ with SAILs in premicellar and postmicellar regions. The enthalpogram of $\left[\mathrm{C}_{6} \mathrm{mim}\right][\mathrm{SDS}]$ and $\left[\mathrm{C}_{12} \mathrm{mim}\right][\mathrm{Cl}]$ aggregation in the absence and presence of $\mathrm{Hb}$ at 298.15 K have been shown in Fig. 6(a) and (b) respectively. To interpret the actual heat changes upon interaction of $\left[\mathrm{C}_{6} \mathrm{mim}\right][\mathrm{SDS}]$ with $\mathrm{Hb}$ the enthalpogram of $\left[\mathrm{C}_{6} \mathrm{mim}\right][\mathrm{SDS}]$ in buffer has been subtracted from $\left[\mathrm{C}_{6} \mathrm{mim}\right][\mathrm{SDS}]$ binding to $\mathrm{Hb}$ and shown in Fig. 6(a). The difference in heat changes due to binding of $\left[\mathrm{C}_{6} \mathrm{mim}\right][\mathrm{SDS}]$ with $\mathrm{Hb}$ clearly demonstrates the presence of interactions between them. The subtracted enthalpogram has been divided into 4 regions marked as region I, II, III and region IV. In monomeric region I $\left(\mathrm{C}_{0}-\mathrm{C}_{1}\right)$ the observed exothermic enthalpy changes reveal the presence of electrostatic interactions between $\left[\mathrm{C}_{6} \mathrm{mim}\right][\mathrm{SDS}]$ monomers and oppositely charged amino acid residues on $\mathrm{Hb}$. In the monomeric concentration region the formation of $\mathrm{Hb}-\left[\mathrm{C}_{6} \mathrm{mim}\right][\mathrm{SDS}]$ monomer complex were also affirmed by various other techniques. With further increasing concentration of $\left[\mathrm{C}_{6} \mathrm{mim}\right][\mathrm{SDS}]$ the enthalpy changes switches to endothermic upto $\mathrm{C}_{2}$ due to the formation of $\mathrm{Hb}-\left[\mathrm{C}_{6} \mathrm{mim}\right][\mathrm{SDS}]$ aggregate complexes guided by electrostatic as well as hydrophobic interactions. The aggregation of $\mathrm{Hb}$ has also been corroborated from turbidity measurements. The $\mathrm{d} H$ value after $\mathrm{C}_{2}$ again starts to decreases before attaining constancy due to the partial dissociation of aggregates and free micelles begins to form upto $\mathrm{C}_{3}$. The observed endothermic heat changes in region III illustrate that
$\left[\mathrm{C}_{6} \mathrm{mim}\right][\mathrm{SDS}]$ micelles form network like structure around $\mathrm{Hb}$ via strong hydrophobic forces. After $\mathrm{C}_{3}$ in region IV the observed enthalpy changes are unchanged due to the reason that binding phenomenon of $\left[\mathrm{C}_{6} \mathrm{mim}\right][\mathrm{SDS}]$ to $\mathrm{Hb}$ reaches saturation and $\left[\mathrm{C}_{6} \mathrm{mim}\right][\mathrm{SDS}]$ molecules gets adsorbed over the surface of $\mathrm{Hb}$. Thus heat changes in region $I$ is correlated with the initial binding of $\left[\mathrm{C}_{6} \mathrm{mim}\right][\mathrm{SDS}]$ monomers to $\mathrm{Hb}$ via electrostatic interactions whereas in regions II and III heat changes are due to conformational changes in $\mathrm{Hb}$ upon binding with $\left[\mathrm{C}_{6} \mathrm{mim}\right]$ [SDS] via electrostatic as well as hydrophobic interactions. The heat changes are unchanged in region IV due to saturation of Hb by SAIL micelles.

The enthalpogram for the binding process of $\left[\mathrm{C}_{12} \mathrm{mim}\right][\mathrm{Cl}]$ to $\mathrm{Hb}$ is shown in Fig. 6(b). The subtracted enthlpogram is divided into 4 regions and unlike $\mathrm{Hb}-\left[\mathrm{C}_{6} \mathrm{mim}\right][\mathrm{SDS}]$ system, $\mathrm{Hb}-$ $\left[\mathrm{C}_{12} \mathrm{mim}\right][\mathrm{Cl}]$ system has less heat changes. In region I, when the concentration of $\left[\mathrm{C}_{12} \mathrm{mim}\right][\mathrm{Cl}]$ is below $\mathrm{C}_{1}$ the observed endothermic heat changes were attributed to the initial binding of $\left[\mathrm{C}_{12} \mathrm{mim}\right][\mathrm{Cl}]$ monomers via weak electrostatic and hydrophobic interactions. The hydrophobic chain of $\left[\mathrm{C}_{12} \mathrm{mim}\right][\mathrm{Cl}]$ interacts with the hydrophobic residues present on the surface of $\mathrm{Hb}$ thus favours the hydrophobic interactions mainly. When $\left[\mathrm{C}_{12} \mathrm{mim}\right][\mathrm{Cl}]$ content is above $\mathrm{C}_{1}$ the $\mathrm{d} H$ values changes with increasing binding of $\left[\mathrm{C}_{12} \mathrm{mim}\right][\mathrm{Cl}]$ aggregates to $\mathrm{Hb}$. In region II the enthalpy changes decreases endothermically and were attributed to conformational changes in $\mathrm{Hb}$. The $\left[\mathrm{C}_{12} \mathrm{mim}\right][\mathrm{Cl}]$ molecules on binding to $\mathrm{Hb}$ causes the geometric distortion and exposed the charged amino acid residues and negatively charged residues which are now free to bind with positively charged head group of $\left[\mathrm{C}_{12} \mathrm{mim}\right][\mathrm{Cl}]$ via electrostatic interactions. The spectroscopic measurement also reveals that after $\mathrm{C}_{2}$ hemichrome is formed and denaturation of $\mathrm{Hb}$ occurs. Thus addition of $\left[\mathrm{C}_{12} \mathrm{mim}\right][\mathrm{Cl}]$ makes the hemoglobin denatured and micelles like aggregates formed at $\mathrm{C}_{2}(12.3 \mathrm{mM})$. In region III when the $\left[\mathrm{C}_{12} \mathrm{mim}\right][\mathrm{Cl}]$ concentration is above $\mathrm{C}_{2}$ the endothermic heat changes were observed upto $\mathrm{C}_{3}$ as denatured $\mathrm{Hb}$ has more hydrophobic chains which are exposed thus $\left[\mathrm{C}_{12} \mathrm{mim}\right]$ $[\mathrm{Cl}]$ induces the heme group to be released from hemoglobin
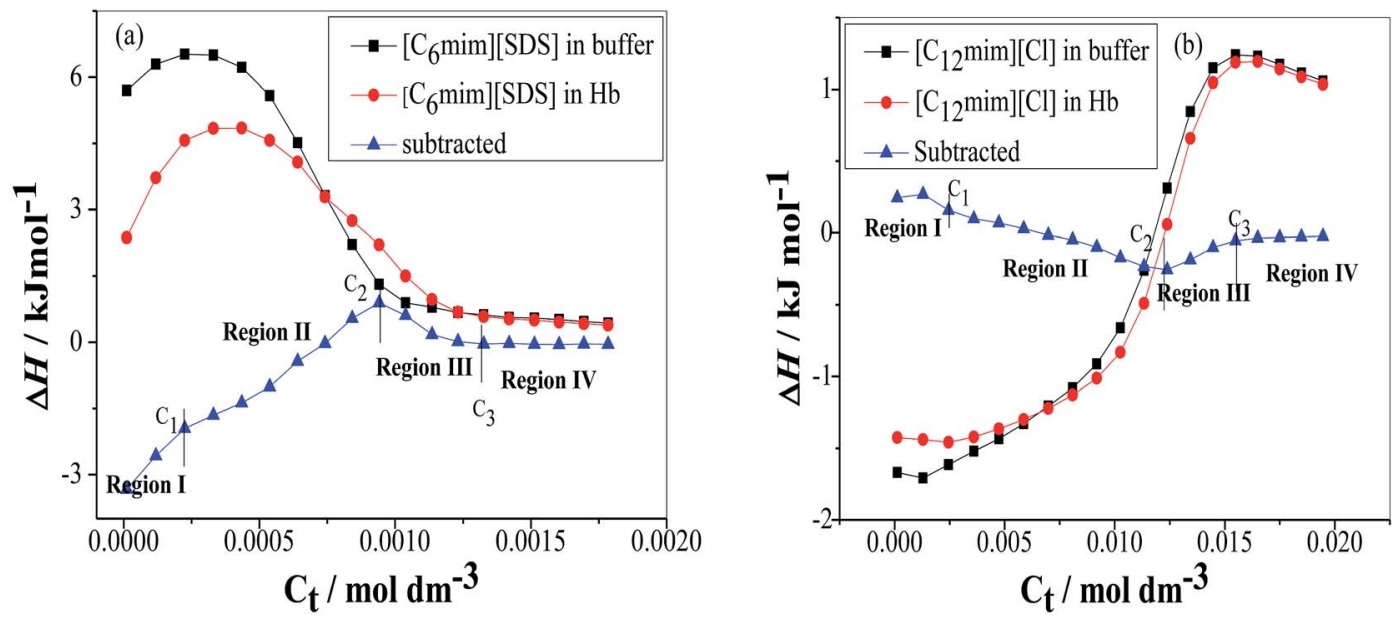

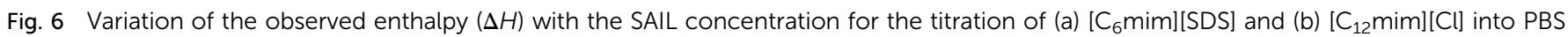
buffer and $\mathrm{Hb}$ in PBS buffer. 

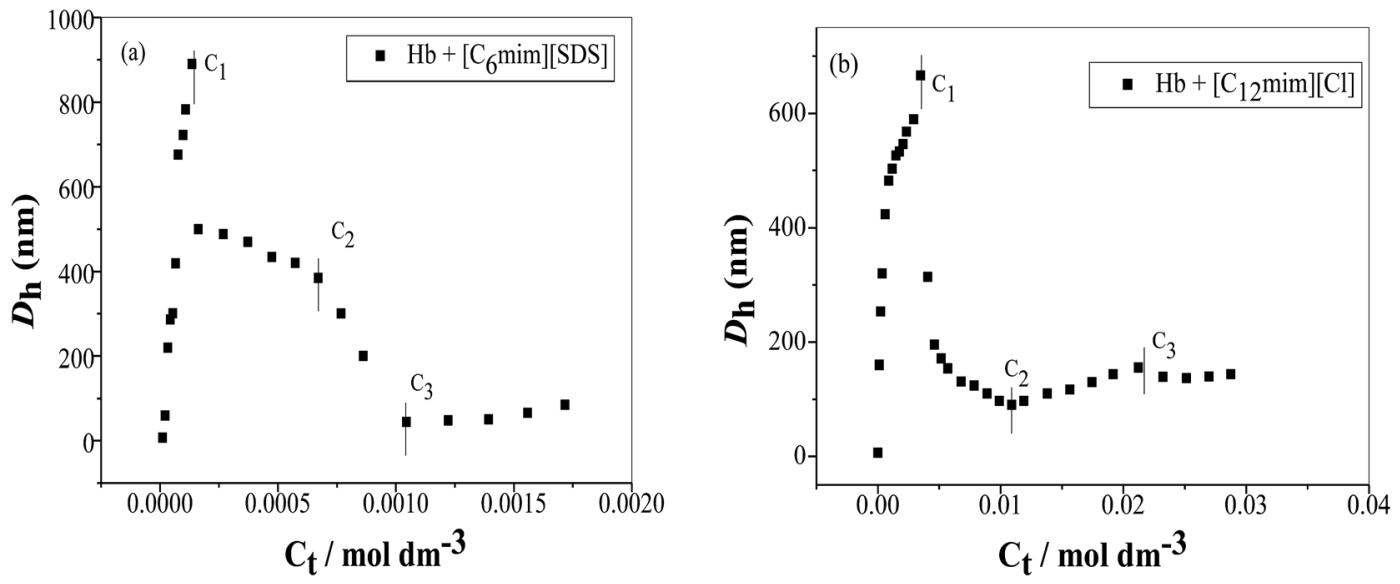

Fig. 7 Variation of the hydrodynamic diameter $\left(D_{h}\right)$ as a function of SAIL concentration (a) $\left[C_{6}\right.$ mim] [SDS] and (b) $\left[C_{12}\right.$ mim] $[C l]$ in $\mathrm{Hb}(5 \mu M)$ solution in PBS buffer.

and subsequently solubilised in the micellar core. After $\mathrm{C}_{3}$ the unchanged or nearly constant heat changes values have been observed due to the saturation of $\mathrm{Hb}$.

\subsection{Dynamic light scattering (DLS) measurements}

DLS measurements were used to investigate the change in size of $\mathrm{Hb}$ upon interacting with SAILs. In the absence of SAILs the apparent size of $\mathrm{Hb}$ in buffer is $6 \mathrm{~nm}$ indicates that protein exist is the form of random coil due to strong hydrophobic interactions among polypeptide chains. The variation in size of $\mathrm{Hb}$ in the presence and absence of SAILs has been shown in Fig. 7(a) and (b). In the presence of $\left[\mathrm{C}_{6} \mathrm{mim}\right][\mathrm{SDS}]$ the hydrodynamic diameter $\left(D_{\mathrm{h}}\right)$ changes from $6 \mathrm{~nm}$ to $7.5 \mathrm{~nm}$ indicate that some kind of interactions take place between $\left[\mathrm{C}_{6} \mathrm{mim}\right][\mathrm{SDS}]$ and $\mathrm{Hb}$. Further with increasing concentration of $\left[\mathrm{C}_{6} \mathrm{mim}\right][\mathrm{SDS}]$ the $D_{\mathrm{h}}$ value reaches $419 \mathrm{~nm}$ indicating the formation of complex between $\mathrm{Hb}$ and $\left[\mathrm{C}_{6} \mathrm{mim}\right][\mathrm{SDS}]$ monomers governed by strong electrostatic and hydrophobic interactions. With further increasing $\left[\mathrm{C}_{6} \mathrm{mim}\right][\mathrm{SDS}]$ concentration, the $D_{\mathrm{h}}$ value sharply increases and reaches upto $\mathrm{C}_{1}$ due to the formation of larger $\mathrm{Hb}-\left[\mathrm{C}_{6} \mathrm{mim}\right][\mathrm{SDS}]$ aggregates or coacervates which makes the solution turbid. After $\mathrm{C}_{1}$ the size sharply decreases from $889 \mathrm{~nm}$ to 380 owing to either disintegration of large sized aggregates or resolubilization of aggregates and the consequence is the disappearance of turbidity. The size of the mixed aggregates continues to decrease till $\mathrm{C}_{3}$ reached because more addition of SAIL induces repulsive interactions which destabilize and breakdown the mixed aggregates. At higher concentration well above $\mathrm{C}_{3}, D_{\mathrm{h}}$ slightly varies indicating the stabilization of mixed aggregates governed by hydrophobic forces between alkyl chain of $\left[\mathrm{C}_{6} \mathrm{mim}\right][\mathrm{SDS}]$ and hydrophobic patches on $\mathrm{Hb}$.

The variation of hydrodynamic diameter $\left(D_{\mathrm{h}}\right)$ of $\mathrm{Hb}$ versus $\left[\mathrm{C}_{12} \mathrm{mim}\right][\mathrm{Cl}]$ concentration has been shown in Fig. $7(\mathrm{~b})$. With the addition of $\left[\mathrm{C}_{12} \mathrm{mim}\right][\mathrm{Cl}]$ the $D_{\mathrm{h}}$ value of $\mathrm{Hb}$ suddenly increased upto $666 \mathrm{~nm}$ indicating that initially hydrophobic chain of $\left[\mathrm{C}_{12} \mathrm{mim}\right][\mathrm{Cl}]$ interact with the hydrophobic moieties of $\mathrm{Hb}$ which results into the formation of large $\mathrm{Hb}-\left[\mathrm{C}_{12} \mathrm{mim}\right][\mathrm{Cl}]$ monomer complex. At $\mathrm{C}_{1}$ the monomer complex transformed into $\mathrm{Hb}-\left[\mathrm{C}_{12} \mathrm{mim}\right][\mathrm{Cl}]$ aggregate complex but with the more addition of $\left[\mathrm{C}_{12} \mathrm{mim}\right][\mathrm{Cl}]$ the large sized $\mathrm{Hb}-\left[\mathrm{C}_{12} \mathrm{mim}\right][\mathrm{Cl}]$ aggregates disintegrate into relatively small sized aggregates thus $D_{\mathrm{h}}$ values decreases sharply upto $195 \mathrm{~nm}$ and after that it decreases slowly upto $C_{2}$. In concentration region $\mathrm{C}_{1}-\mathrm{C}_{2}$ conformational changes occurs in $\mathrm{Hb}$ and folded structure of $\mathrm{Hb}$ can be expected to form with the loss of superoxide anion with the release of heme monomer. These results are also justified from UV-visible results where pentacoordinated species is formed with the release of heme. After $\mathrm{C}_{2}$ with further addition of $\left[\mathrm{C}_{12} \mathrm{mim}\right][\mathrm{Cl}]$ hydrophobic interactions increases which induces the heme monomer to leave the hydrophobic pocket of protein thus size increases but only upto $\mathrm{C}_{3}$. Once $\mathrm{C}_{3}$ reached the $D_{\mathrm{h}}$ value remains unchanged due to the saturation of $\mathrm{Hb}$ with the addition of more $\left[\mathrm{C}_{12} \mathrm{mim}\right][\mathrm{Cl}]$.

\section{Conclusions}

In conclusion, in this work we have studied the comparative studies on the interactions of $\mathrm{Hb}$ with $\left[\mathrm{C}_{6} \mathrm{mim}\right][\mathrm{SDS}]$ and $\left[\mathrm{C}_{12} \mathrm{mim}\right][\mathrm{Cl}]$ with the aid of various techniques. The surface tension measurements have been performed to study the interactional behavior at the air-solution interface and the results have been discussed in detail giving various transitional concentrations and evaluating $\tau_{\max }$ and $A_{\min }$ values. The binding mechanism and structural alterations in $\mathrm{Hb}$ induced by SAILs have been thoroughly studied using spectroscopic measurements. The results based on the experiments confirms the formation of hemichrome in Hb-SAIL systems but the ejection of heme from $\mathrm{Hb}$ hydrophobic pocket to micellar core takes place only in $\mathrm{Hb}-\left[\mathrm{C}_{12} \mathrm{mim}\right][\mathrm{Cl}]$ system, whereas the long alkyl chain of $\left[\mathrm{C}_{6} \mathrm{mim}\right][\mathrm{SDS}]$ forms network like structure and prevent the release of heme molecule thus hemichrome remains stabilized. The addition of $\left[\mathrm{C}_{6} \mathrm{mim}\right][\mathrm{SDS}]$ to $\mathrm{Hb}$ leads to aggregation of protein which is evidenced from appearance of turbidity and appearance of larger aggregates in DLS measurements. Despite these investigations, ITC measurements were also performed to investigate the enthalpy changes and exact 
nature of molecular interactions present in Hb-SAIL system. As protein-surfactant systems are consistent with the biological membranes so gives the opportunity to explore surface active ionic liquids to understand various biomembrane-protein functions. Our findings provide an important insight into the $\mathrm{Hb}$-SAIL interactions essential for determining their future use as excipients in pharmaceutical formulations containing proteins. These results may also show the potential utility of $\mathrm{Hb}$-SAILs interactions in biotechnological processes and pharmaceutical formulations.

\section{Acknowledgements}

Financial support by the University Grants Commission (UGC), New Delhi [Project F. No. 42-278/2013 (SR)] and Department of Science and Technology [DST, New Delhi (Project No. SR/S1/PC02/2011)] is highly acknowledged. One of the authors RV is thankful to UGC-BSR for the award of Research Fellow.

\section{References}

1 E. L. Kovrigin and S. A. Potekhin, On The Stabilizing Action of Protein Denaturants: Acetonitrile Effect on Stability of Lysozyme In Aqueous Solutions, Phys. Chem. Chem. Phys., 2000, 83, 45-59.

2 J. W. Kelly, The Alternative Conformations of Amyloidogenic Proteins and Their Multi-step Assembly Pathways, Curr. Opin. Struct. Biol., 1998, 8, 101-106.

3 M. Nagai, M. Aki, R. Li, Y. Jin, H. Sakai, S. Nagatomo and T. Kitagawa, Heme Structure of Hemoglobin $\mathbf{M}$ Iwate [ $\alpha 87($ F8)His $\rightarrow$ Tyr]: A UV and Visible Resonance Raman Study, Biochemistry, 2000, 39, 13093-13105.

4 C. H. Fan, H. Y. Wang, S. Sun, D. X. Zhu, G. Wagner and G. X. Li, Electron-Transfer Reactivity and Enzymatic Activity of Hemoglobin in a SP Sephadex Membrane, Anal. Chem., 2001, 73, 2850-2854.

5 M. F. Perutz, Stereochemistry of Cooperative Effects in Haemoglobin, Nature, 1970, 228, 726-734.

6 D. J. Wang, X. J. Zhao, T. J. Shen, C. Ho and T. G. Spiro, Role of Interhelical H-Bonds (W $\alpha 14-\mathrm{T} \alpha 67$ and $\mathrm{W} \beta 15-\mathrm{S} \beta 72$ ) in the Hemoglobin Allosteric Reaction Path Evaluated by UV Resonance Raman Spectroscopy of Site-Mutants, J. Am. Chem. Soc., 1999, 121, 11197-11203.

7 S. Maulik, P. Dutta, D. K. Chattoraj and S. P. Moulik, Biopolymer-Surfactant Interactions: 5 Equilibrium Studies on the Binding of Cetyltrimethyl Ammonium Bromide and Sodium Dodecylsulfate with Bovine Serum Albumin, $\beta$ Lactoglobulin, Hemoglobin, Gelatin, Lysozyme and Deoxyribonucleic Acid, Colloids Surf., B, 1998, 11, 1-8.

8 D. Ajloo, A. A. M. Movahedi, G. H. Hakimelahi, A. A. Saboury and H. Gharibi, The Effect of Dodecyltrimethylammonium Bromide on the Formation of Methemoglobins and Hemichrome, Colloids Surf., B, 2002, 26, 185-196.

9 E. A. Rachmilewitz, J. Peisach, T. B. Bradley and W. E. Blumberg, Role of Haemichromes in the Formation of Inclusion Bodies in Haemoglobin H Disease, Nature, 1969, 222, 248-250.
10 A. N. Schechter, Hemoglobin Research and the Origins of Molecular Medicine, Blood, 2008, 112, 3927-3938.

11 M. N. Jones, Surfactant Interactions with Biomembranes and Proteins, Chem. Soc. Rev., 1992, 21, 127-136.

12 A. Chakraborty, D. Seth, P. Setua and N. Sarkar, Photoinduced Electron Transfer in a Protein-Surfactant Complex: Probing The Interaction of SDS with BSA, J. Phys. Chem. B, 2006, 110, 16607-16617.

13 B. Orioni, M. Roversi, C. La Mesa, C. Asaro, F. Asaro, G. Pellizer and G. D. Errico, Polymorphic Behavior in Protein-Surfactant Mixtures: The Water-Bovine Serum Albumin-Sodium Taurodeoxycholate System, J. Phys. Chem. $B, 2006,110,12129-12140$.

14 A. Stenstam, G. Montalvo, I. Grillo and M. Gradzielski, Small Angle Neutron Scattering Study of Lysozyme-Sodium Dodecyl Sulfate Aggregates, J. Phys. Chem. B, 2003, 107, 12331-12338.

15 D. Kelley and D. J. McClements, Interactions of Bovine Serum Albumin with Ionic Surfactants in Aqueous Solutions, Food Hydrocolloids, 2003, 17, 73-85.

16 Y. Moriyama, Y. Kawasaka and K. Takeda, Protective Effect of Small Amounts of Sodium Dodecylsulfate on the Helical Structure of Bovine Serum Albumin in Thermal Denaturation, J. Colloid Interface Sci., 2003, 257, 41-46.

17 E. L. Gelamo, R. Itri, A. Alonso, J. V. da Silva and M. Tabak, Small Angle X-ray Scattering and Electron Paramagnetic Resonance Study of the Interaction of Bovine Serum Albumin with Ionic Surfactants, J. Colloid Interface Sci., 2004, 277, 471-482.

18 B. Sarriona, E. Bernal, V. I. Martin, M. L. Lopez, P. L. Cornejo, M. G. Calderon and M. L. Moya, Binding of 12-s-12 Dimeric Surfactants to Calf thymus DNA: Evaluation of the Spacer Length Influence, Colloids Surf., B, 2016, 144, 311-318.

19 M. Akram, I. A. Bhat, S. Anwar and A. Ahmad, K-ud Din, Biophysical Perspective of the Binding of Esterfunctionalized Gemini Surfactants with Catalase, Int. J. Biol. Macromol., 2016, 88, 614-623.

20 L. Gebicka and E. Banasiak, Interactions of Anionic Surfactants with Methemoglobin, Colloids Surf., B, 2011, 83, 116-121.

21 W. Liu, X. Guo and R. Guo, The interaction of Hemoglobin with Hexadecyltrimethylammonium Bromide, Int. J. Biol. Macromol., 2005, 37, 232-238.

22 G. Prieto, J. Sabin, J. M. Ruso, A. Gonzalez-Perez and F. Sarmiento, A Study of the Interaction between Proteins and Fully-Fluorinated and Fully-Hydrogenated Surfactants by $\zeta$-Potential Measurements, Colloids Surf., A, 2004, 249, 51-55.

23 P. D. Galgano and O. A. El Seoud, Surface Active Ionic Liquids: Study of the Micellar Properties of 1-(1-alkyl)-3Methylimidazolium Chlorides and Comparison with Structurally Related Surfactants, J. Colloid Interface Sci., 2011, 361, 186-194.

24 A. Cornellas, L. Perez, F. Comelles, I. Ribosa, A. Manresa and M. T. Garcia, Self-Aggregation and Antimicrobial Activity of Imidazolium and Pyridinium Based Ionic Liquids in 
Aqueous Solution, J. Colloid Interface Sci., 2011, 355, 164171.

25 A. M. Dattelbaum, S. N. Baker and G. A. Baker, $N$-Alkyl- $N$ methylpyrrolidinium Salts as Templates for Hexagonally Meso-ordered Silicate Thin Films, Chem. Commun., 2005, 939-941.

26 T. Wang, H. Kaper, M. Antonietti and B. Smarsly, Templating Behavior of a Long-Chain Ionic Liquid in the Hydrothermal Synthesis of Mesoporous Silica, Langmuir, 2007, 23, 14891495.

27 J. Bowers, C. P. Butts, P. J. Martin, M. C. Vergara-Gutierrez and R. K. Heenan, Aggregation Behavior of Aqueous Solutions of Ionic Liquids, Langmuir, 2004, 20, 2191-2198.

28 J. Luczak, J. Hupka, J. Thoming and C. Jungnickel, SelfOrganization of Imidazolium Ionic Liquids in Aqueous Solution, Colloids Surf., A, 2008, 329, 125-133.

29 B. Dong, N. Li, L. Zheng, L. Yu and T. Inoue, Surface Adsorption and Micelle Formation of Surface Active Ionic Liquids in Aqueous Solution, Langmuir, 2007, 23, 4178-4182.

30 M. Blesic, M. Swadzba-Kwasny, J. D. Holbrey, J. N. C. Lopes, K. R. Seddon and L. P. N. Rebelo, New Catanionic Surfactants Based on 1-alkyl-3-methylimidazolium Alkylsulfonates, $\quad\left[\mathrm{C}_{n} \mathrm{H}_{2 n+1} \mathrm{mim}\right]\left[\mathrm{C}_{m} \mathrm{H}_{2 m+1} \mathrm{SO}_{3}\right]$ : Mesomorphism and Aggregation, Phys. Chem. Chem. Phys., 2009, 11, 4260-4268.

31 R. T. W. Huang, K. C. Peng, H. N. Shih, G. H. Lin, T. F. Chang, S. J. Hsu, T. S. T. Hsu and I. J. B. Lin, Antimicrobial properties of ethoxyether-functionalized imidazolium salts, Soft Matter, 2011, 7, 8392-8400.

32 T. Singh, S. Boral, H. B. Bohidar and A. Kumar, Interaction of Gelatin with Room Temperature Ionic Liquids: A Detailed Physicochemical Study, J. Phys. Chem. B, 2010, 114, 84418448.

33 M. C. Miller, S. L. Hanna, K. G. DeFrates, O. C. Fiebig and T. D. Vaden, Kinetics and Mass Spectrometric Measurements of Myoglobin unfolding in Aqueous Ionic Liquid Solutions, Int. J. Biol. Macromol., 2016, 85, 200-207.

34 Y. Shu, M. Liu, S. Chen, X. Chen and J. Wang, New Insight into Molecular Interactions of Imidazolium Ionic Liquids with Bovine Serum Albumin, J. Phys. Chem. B, 2011, 115, 12306-12314.

35 S. Chabba, R. Vashishat and R. K. Mahajan, Influence of Head Group on the Interactional Behavior of Cationic Surface Active Ionic Liquids with Pluronic F108 in Aqueous Medium, J. Mol. Liq., 2016, 222, 691-702.

36 Q. Zhang, W. Kang, D. Sun, J. Liu and X. Wei, Interaction Between Cationic Surfactant of 1-methyl-3tetradecylimidazolium Bromide and Anionic Polymer of Sodium Polystyrene Sulfonate, Appl. Surf. Sci., 2013, 279, 353-359.

37 M. Gericke, T. Liebert and T. Heinze, Interaction of Ionic Liquids with Polysaccharides, 8 - Synthesis of Cellulose Sulfates Suitable for Polyelectrolyte Complex Formation, Macromol. Biosci., 2009, 9, 343-353.

38 I. Jha, A. Kumar and P. Venkatesu, The Overriding Roles of Concentration and Hydrophobic Effect on Structure and
Stability of Heme Protein Induced by Imidazolium-Based Ionic Liquids, J. Phys. Chem. B, 2015, 119, 8357-8368.

39 I. Jha and P. Venkatesu, Unprecedented Improvement in the Stability of Hemoglobin in the Presence of Promising Green Solvent 1-Allyl-3-methylimidazolium Chloride, ACS Sustainable Chem. Eng., 2016, 4, 413-421.

40 X. Chen, X. Yang, W. Zeng and J. Wang, Dynamic Mass Transfer of Hemoglobin at the Aqueous/Ionic-Liquid Interface Monitored with Liquid Core Optical Waveguide, Langmuir, 2015, 31, 8379-8385.

41 J. Dupont, C. S. Consorti, P. A. Z. Suarez and R. F. Souza, Preparation Of 1-Butyl-3-Methyl Imidazolium-Based Room Temperature Ionic Liquids, Org. Synth., 2002, 79, 236-241.

42 T. Singh, M. Drechsler, A. H. E. Mueller, I. Mukhopadhyaya and A. Kumar, Micellar Transitions in the Aqueous Solutions of a Surfactant-like Ionic Liquid: 1-butyl-3methylimidazolium octylsulfate, Phys. Chem. Chem. Phys., 2010, 12, 11728-11735.

43 K. S. Rao, T. J. Trivedi and A. Kumar, Aqueous-Biamphiphilic Ionic Liquid Systems: Self-Assembly and Synthesis of Gold Nanocrystals/Microplates, J. Phys. Chem. B, 2012, 116, 14363-14374.

44 Y. Li, X. Wang and Y. Wang, Comparative Studies on Interactions of Bovine Serum Albumin with Cationic Gemini and Single-Chain Surfactants, J. Phys. Chem. B, 2006, 110, 8499-8505.

45 Y.-Q. Wang, H.-M. Zhang and B.-P. Tang, The Interaction of C. I. Acid Red 27 with Human Hemoglobin in Solution, $J$. Photochem. Photobiol., B, 2010, 100, 76-83.

46 K. Rawat, J. Pathak and H. B. Bohidar, Effect of Persistence Length on Binding of DNA to Polyions and Overcharging of their Intermolecular Complexes in Aqueous and in 1methyl-3-octylimidazolium Chloride Ionic Liquid Solutions, Phys. Chem. Chem. Phys., 2013, 15, 12262-12273.

47 F. Geng, L. Zheng, L. Yua, G. Li and C. Tung, Interaction of Bovine Serum Albumin and Long-Chain Imidazolium Ionic Liquid Measured by Fluorescence Spectra and Surface Tension, Process Biochem., 2010, 45, 306-311.

48 S. Guillot, M. Delsanti, S. Desert and D. Langevin, SurfactantInduced Collapse of Polymer Chains and Monodisperse Growth of Aggregates near the Precipitation Boundary in Carboxymethylcellulose-DTAB Aqueous Solutions, Langmuir, 2003, 19, 230-237.

49 M. Mahato, P. Pal, T. Kamilya, R. Sarkar, A. Chaudhuri and G. B. Talapatra, Hemoglobin-Silver Interaction and Bioconjugate Formation: A Spectroscopic Study, J. Phys. Chem. B, 2010, 114, 7062-7070.

$50 \mathrm{Y}$. Wang, R. Guo and J. Xi, Comparative Studies of Interactions of Hemoglobin with Single-Chain and with Gemini Surfactants, J. Colloid Interface Sci., 2009, 331, 470475.

51 H. Tajima, S. Ikeda, M. Matsuda, N. Hanasaki, J. W. Oh and H. Akiyama, A Light-Emitting Diode Fabricated from HorseHeart Cytochrome c, Solid State Commun., 2003, 126, 579581.

52 P. Bharmoria, T. J. Trivedi, A. Pabbathi, A. Samanta and A. Kumar, Ionic Liquid-Induced all- $\alpha$ to $\alpha+$ 
$\beta$ Conformational Transition in Cytochrome $\mathrm{c}$ with Improved Peroxidase Activity in Aqueous Medium, Phys. Chem. Chem. Phys., 2015, 17, 10189.

53 Y. Sugawara, A. Matsuoka, A. Kaino and K. Shikama, Role of Globin Moiety in the Autoxidation Reaction of Oxymyoglobin: Effect of 8 M Urea, Biophys. J., 1995, 69, 583-592.

54 K. Shikama, Stability Properties Of Dioxygen-Iron(II) Porphyrins: An Overview from Simple Complexes to Myoglobin, Coord. Chem. Rev., 1988, 83, 73-91.

55 K. Shikama, A Controversy on the Mechanism of Autoxidation of Oxymyoglobin and Oxyhaemoglobin: Oxidation, Dissociation, or Displacement?, Biochem. J., 1984, 223, 279-280.

56 W. Liu, X. Guo and R. Guo, The interaction between hemoglobin and two surfactants with different charges, Int. J. Biol. Macromol., 2007, 41, 548-557.
$57 \mathrm{M}$. Tsuruga and K. Shikama, Biphasic Nature in the Autoxidation Reaction of Human Oxyhemoglobin, Biochim. Biophys. Acta, 1997, 1337, 96-104.

58 R. E. Hirstch, Hemoglobin Fluorescence, Methods Mol. Med., 2003, 82, 133-154.

59 P. S. Santiago, L. M. Moreira, E. V. de Almeida and M. Tabak, Giant Extracellular Glossoscolex Paulistus Hemoglobin (HbGp) upon Interaction with Cethyltrimethylammonium Chloride (CTAC) and Sodium Dodecylsulphate (SDS) Surfactants: Dissociation of Oligomeric Structure and Autoxidation, Biochim. Biophys. Acta, 2007, 1770, 506-517.

60 S. Kamimura, A. Matsuoka, K. Imai and K. Shikama, The Swinging Movement of the Distal Histidine Residue and the Autoxidation Reaction for Midge Larval Hemoglobins, Eur. J. Biochem., 2003, 270, 1433-1474.

61 S. Q. Liu, J. J. Xu and H. Y. Chen, A Reversible AdsorptionDesorption Interface of DNA Based on Nano-Sized Zirconia and its Application, Colloids Surf., B, 2004, 36, 155-159. 